\title{
Purification and characterization of phycocyanin from the marine cyanobacterium Synechococcus sp. IO9201
}

Julio Abalde $*^{, a,}$, Liliana Betancourt ${ }^{\mathrm{a}, \mathrm{b}}$, Enrique Torres ${ }^{\mathrm{a}}$, Ángeles Cid $^{\mathrm{a}}$, Clive Barwell ${ }^{\mathrm{c}}$

áLaboratorio de Microbiología, Facultad de Ciencias, Universidade da Coruña, Campus da Zapateira s/n, 15071 A Coruña, Spain

${ }^{\mathrm{b}}$ Instituto de Oceanología, La Habana, Cuba

${ }^{\mathrm{c}}$ School of Pharmacy and Biomedical Science, University of Portsmouth, Portsmouth, UK

Plant Science, Volume 136, Issue 1, 7 August 1998, Pages 109-120

Received 26 February 1998, Revised 3 June 1998, Accepted 8 June 1998

\section{How to cite}

J. Abalde, L. Betancourt, E. Torres, Á. Cid, C. Barwell, Purification and characterization of phycocyanin from the marine cyanobacterium Synechococcus sp. IO9201, Plaw Science, 136 (1998) 109 - 120. doi:10.1016/S01689452(98)00113-7

\section{Abstract}

This paper describes a suitable method for the optimum extraction and isolation of phycocyanin from the cyanobacterium Synechococcus sp. IO9201 isolated from Caribbean waters. Phycocyanin from this microorganism was purified to homogeneity and some of its properties were investigated. The purification steps consisted of extraction, hydrophobic interaction chromatography and ion exchange chromatography. 
Freezing at $-21^{\circ} \mathrm{C}$-thawing at $4^{\circ} \mathrm{C}$, using an alkaline buffer was the best method for extracting phycocyanin from Synechococcus sp. IO9201. The best extraction was obtained using butyl-sepharose resin for hydrophobic interaction chromatography and $0.05 \mathrm{M}$ Tris- $\mathrm{HCl}(\mathrm{pH}=7)$ containing $10 \%$ ethanol for phycocyanin elution. Finally, phycocyanin was further purified by ion exchange chromatography using Q-sepharose and eluted with a complex isocratic system. The estimated molecular weight of the phycocyanin purified from Synechococcus sp. IO9201 was 102000 daltons by gel filtration and the isoelectric point was 4.6. When analyzed by SDSPAGE, Synechococcus sp. IO9201 phycocyanin migrated as two bands having an apparent molecular weight of 21360 and $18980 \mathrm{Da}$. The first band corresponds to $\beta$ phycocyanin subunits, whereas the second corresponds to $\alpha$ phycocyanin subunits. So, this phycocyanin was characterized as $\left(\alpha^{\mathrm{CPC}} \beta^{\mathrm{CPC}}\right)_{3}$.

\section{Keywords:}

Phycocyanin; Protein purification: Cyanobacteria; Synechococcus sp.

\section{INTRODUCTION}

The phycobiliproteins are pigments present in cyanobacteria, red algae and cryptomonads. They are in association with the outer surface of the photosynthetic lamellae, being constituents of the photosystem II light-harvesting apparatus. The phycobiliproteins are organized into supramolecular complexes, the phycobilisomes, which are found as regular arrays on the surface of thylakoid membranes [1 ,2]. Phycobiliproteins are a brilliantly colored family of water-soluble proteins bearing covalently attached, open-chain tetrapyrroles known as phycobilins. On the basis of their visible absorption properties, the phycobiliproteins have been assigned to four spectroscopic classes: phycoerythrocyanin (PEC, $\lambda_{\text {Amax }}=575 \mathrm{~nm}$ ), phycoerythrins $(\mathrm{PE}$, $\left.\lambda_{\text {Amax }}=565-575 \mathrm{~nm}\right)$, phycocyanins $\left(\mathrm{PC}, \lambda_{\mathrm{Amax}}=640 \mathrm{~nm}\right)$ and allophycocyanin $(\mathrm{APC}$, $\lambda_{\text {Amax }}=650-655 \mathrm{~nm}$ ) [3]. Phycobilisomes consist of allophycocyanin cores surrounded by phycocyanin and (when present) phycoerythrin on the periphery. Several colorless polypeptides serve to link phycobiliproteins in the phycobilisome and to attach them to the thylakoid membrane [4]. The fundamental unit of all phycobiliproteins consists of 
the trimeric or hexameric aggregation $(\alpha \beta)_{3},(\alpha \beta)_{6}$ of two dissimilar polypeptides, $a$ and $\beta$ subunits present in an equimolecular stoichiometry [5-7]. Phycobiliproteins are easily isolated as pigment-protein complexes, soluble in water and very fluorescent [8J. Thus, the purification procedure is facilitated because the phycobiliproteins are very soluble in water, allowing to separate these molecules from other pigments that are not. These molecules have been extracted from algae and cyanobacteria by different methods [9J, but appropriate control of ionic strength and $\mathrm{pH}$ during the extraction procedure is crucial for complex stability. Purification methods usually rely on gel, adsorption and ion exchange chromatography $[6,10,11]$. Present purification procedure consists of three steps: extraction, hydrophobic and ion exchange chromatography.

Some characteristics of phycobiliproteins make them well-suited for fluorescence analyses as fluorescent tags with numerous applications in flow cytometry, histochemistry, immunoassay and detection of reactive oxygen species [12]. They can also be used as natural dyes [1 3] and antitumoral agents [14].

This paper describes a suitable method for the optimum extraction and isolation of phycocyanin from the cyanobacterium Synechococcus sp. IO9201. Synechococcus spp. are important components of the marine microbial food web. These organisms are widely distributed, occurring in both oligotrophic waters as well as in temperate coastal and oceanic waters $[15,16]$.

\section{MATERIALS AND METHODS}

\subsection{Organism and culture conditions}

The marine cyanobacterium Synechococcus sp. I09201 was obtained from the Culture Collection of Instituto de Oceanología of Cuba. This organism was cultured in ALGAL-1 medium [17] at $18 \pm 1^{\circ} \mathrm{C}$ with constant bubbling of air at a flow rate of 21 $\min ^{-1}$. Cultures were illuminated with a light intensity of $60 \mu \mathrm{E} \mathrm{m}^{-2} \mathrm{~s}^{-1}$, provided by cool-white fluorescent tubes and with a dark:light cycle of 12: $12 \mathrm{~h}$.

\subsection{Preparation of cell-free extracts}

Cells were harvested by centrifugation at $5000 \mathrm{x} g$ for $5 \mathrm{~min}$ and resuspended in distilled water. Three extraction methods were assayed: 
- $\quad$ sonication at $4{ }^{\circ} \mathrm{C}$ : resuspended cells were disrupted by sonication for $5 \mathrm{~min}$ at $10^{4}$ Kcycles $^{-1}$. The extract was clarified by centrifugation at $10000 \mathrm{x} \mathrm{g}$ for 15 min.

- freezing in liquid $\mathrm{N}_{2}$ - thawing at $4^{\circ} \mathrm{C}$ : resuspended cells were frozen in liquid $\mathrm{N}$, and thawed at $4^{\circ} \mathrm{C}$ three times. The extract was clarified by centrifugation at $10000 \mathrm{x} g$ for $15 \mathrm{~mm}$.

- freezing at $-21^{\circ} \mathrm{C}$-thawing at $4^{\circ} \mathrm{C}$ : resuspended cells were successively frozen at $-21^{\circ} \mathrm{C}$ and thawed at $4^{\circ} \mathrm{C}$ three times. The extract was clarified by centrifugation at $10000 \times \mathrm{x}$ for $15 \mathrm{~min}$. Different extraction solutions were assayed with this method: distilled water, $10 \mathrm{mM}$ phosphate buffer $(\mathrm{pH}=7)$, $0.15 \mathrm{M}$ sodium chloride, $0.05 \mathrm{M}$ Tris- $\mathrm{HCl}(\mathrm{pH}=7)$, calcium chloride $10 \mathrm{~g} \mathrm{l}^{-}$ 1 and an alkaline buffer composed of $0.5 \mathrm{~g} \mathrm{l}^{-1} \mathrm{NaHCO}_{3}$ and $0.5 \mathrm{~g} \mathrm{l}^{-1} \mathrm{CaCO}_{3}$, $(\mathrm{pH}=10.5)$. All solutions contained $0.05 \%$ sodium azide to avoid microbial growth.

The phycocyanin concentration and purity in the supernatants were measured and calculated as described in Section 2.3.

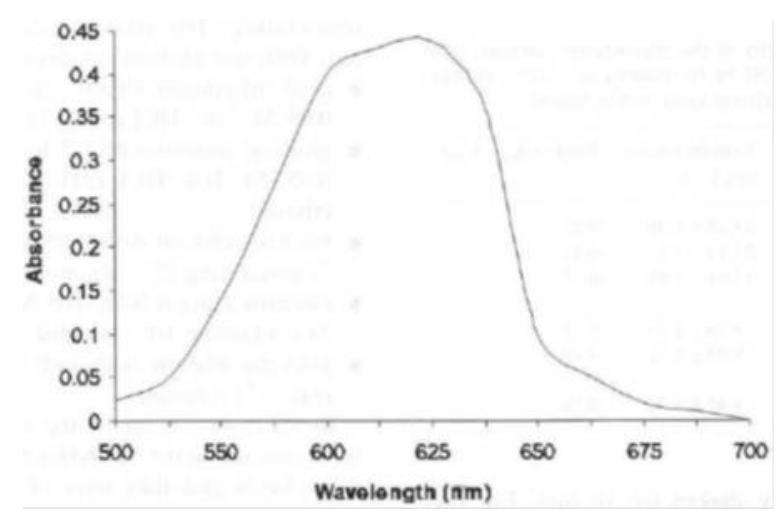

Fig. 1. Absorption spectra of purified C-phycocyanin from Synechococcus sp. IO9201.

\subsection{Analytical procedures}

Phycocyanin concentration: the phycocyanin (PC) concentration in the supernatants was calculated by spectrophotometric absorption at 652 and $615 \mathrm{~nm}$ using following equation [18]:

$\mathrm{PC}\left(\mathrm{mg} \mathrm{m} \mathrm{l}^{-1}\right)=\left(A_{615}-0.474\left(A_{652}\right)\right) / 5.34$ 
Purification factor: the purity of phycocyanin extract was monitored spectrophotometrically by the $A_{620} / A_{280}$ ratio.

\subsection{Evaluation of the purification method}

Hydrophobic interaction chromatography and ion exchange chromatography were used and evaluated as a two-step procedure for purifying the extracted phycocyanin obtained from the cyanobacterium Synechococcus sp. IO9201.

\subsubsection{Hydrophobic interaction chromatography}

Resin evaluation. Different resins were assayed for the phycocyanin purification: butyl-sepharose4-fast flow, octyl-sepharoseCL-4B and phenyl-sepharose6- fast flow (Pharmacia). $0.5 \mathrm{ml}$ of each resin was placed in a tube and equilibrated with $0.05 \mathrm{M}$ Tris- $\mathrm{HCl}(\mathrm{pH}=7)$ containing $0.5 \mathrm{M}\left(\mathrm{NH}_{4}\right)_{2} \mathrm{SO}_{4}$. After equilibration, the resins were centrifuged at $700 \times g$ for $2 \mathrm{~min}$ and the supernatant was discarded. The resins were loaded with $2 \mathrm{~m}$ ( of the Synechococcus sp. IO9201 phycocyanin extract in the presence of solid $\left(\mathrm{NH}_{4}\right)_{2} \mathrm{SO}_{4}$ at a final concentration of $0.5 \mathrm{M}$. The mixture was gently shaken for $10 \mathrm{~min}$. For pigment release, different solutions were assayed and added to each tube: decreasing concentrations of $\left(\mathrm{NH}_{4}\right)_{2} \mathrm{SO}_{4}(0.5,0.25,0.125$ and $0 \mathrm{M})$ prepared in $0.05 \mathrm{M}$ Tris- $\mathrm{HCl}(\mathrm{pH}=7)$ and $20 \%$ ethanol in $0.05 \mathrm{M}$ Tris- $\mathrm{HCl}(\mathrm{pH}=7)$. After $10 \mathrm{~min}$, the resin with each solution was centrifuged at $700 \mathrm{x} g$ for $2 \mathrm{~min}$, and the supernatants were monitored spectrophotometrically.

Table 1

Comparison of different methods for the extraction of phycocyanin from Synechococcus sp. IO9201 using distilled water as solvent

\begin{tabular}{|c|c|c|}
\hline Extraction method & $\begin{array}{l}\text { Concentration } \\
\left(\mu \mathrm{g} \mathrm{ml}^{-1}\right)\end{array}$ & Purity $\left(A_{620} / A_{280}\right)$ \\
\hline Sonication at $4^{\circ} \mathrm{C}$ & $7.44 \pm 0.02$ & 0.1 \\
\hline $\begin{array}{c}\text { Freezing at }-21^{\circ} \mathrm{C}- \\
\text { thawing at } 4^{\circ} \mathrm{C}\end{array}$ & $13.42 \pm 0.02$ & 0.27 \\
\hline $\begin{array}{l}\text { Freezing in liquid } \\
\mathrm{N}_{2} \text {-thawing at } 4^{\circ} \mathrm{C}\end{array}$ & $9.41 \pm 0.01$ & 0.18 \\
\hline
\end{tabular}

Table 2

Concentration and purity of the phycocyanin extracted from Synechococcus sp. 109201 by the freezing at $-21^{\circ} \mathrm{C}$-thawing at $4^{\circ} \mathrm{C}$ method with different extraction solutions

\begin{tabular}{|c|c|c|}
\hline Extraction solution & $\begin{array}{l}\text { Concentration } \\
\left(\mu \mathrm{g}^{-1}\right)\end{array}$ & Purity $\left(A_{620} / A_{280}\right)$ \\
\hline Distilled water & $13.42 \pm 1.46$ & 0.27 \\
\hline Alkaline phase & $27.11 \pm 3.6$ & 0.43 \\
\hline $\begin{array}{l}\text { Tris- } \mathrm{HCl} 0.05 \mathrm{M} \\
\quad(\mathrm{pH}=7)\end{array}$ & $12.91 \pm 1.91$ & 0.25 \\
\hline Calcium chloride & $9.76 \pm 1.16$ & 0.25 \\
\hline $\begin{array}{l}\text { Phosphate buffer } 10 \\
\mathrm{mM}(\mathrm{pH}=7)\end{array}$ & $9.47 \pm 1.32$ & 0.19 \\
\hline Sodium chloride & $9.42 \pm 0.37$ & 0.18 \\
\hline
\end{tabular}

Purification on butyl-sepharose4- fast flow. A phycocyanin extract was chromatographed on a butyl-sepharose column (Pharmacia XK26) $(2 \times 2.6 \mathrm{~cm})$ at a flow rate of $2 \mathrm{ml} \mathrm{min}^{-1}$ and at room temperature. The elution was monitored at $620 \mathrm{~nm}$. Different elution conditions were assayed: 
- $\quad$ gradient elution with 0.5 to $0 \mathrm{M}\left(\mathrm{NH}_{4}\right)_{2} \mathrm{SO}_{4}$ in $0.05 \mathrm{M}$ Tris- $\mathrm{HCl}(\mathrm{pH}=7)$.

- gradient elution with 0.5 to $0 \mathrm{M}\left(\mathrm{NH}_{4}\right)_{2} \mathrm{SO}_{4}$ in $0.05 \mathrm{M}$ Tris- $\mathrm{HCl}(\mathrm{pH}=7)$ containing $50 \%$ ethanol.

- $\quad$ isocratic elution with $0.05 \mathrm{M}$ Tris- $\mathrm{HCl}(\mathrm{pH}=7)$ containing $25 \%$ ethanol.

- $\quad$ isocratic elution with $0.05 \mathrm{M}$ Tris- $\mathrm{HCl}(\mathrm{pH}=7)$ containing $10 \%$ ethanol.

- $\quad$ isocratic elution with only $0.05 \mathrm{M}$ Tris- $\mathrm{HCl}(\mathrm{pH}=7)$ solution.

In all cases, $20 \mathrm{ml}$ of the pigment-protein extract containing $0.5 \mathrm{M}\left(\mathrm{NH}_{4}\right)_{2} \mathrm{SO}_{4}$ were applied to the column and they were eluted with $50 \mathrm{ml}$ of each mobile phase. The fractions obtained were characterized spectrophotometrically.

\subsubsection{Ion exchange chromatography}

The phycocyanin fraction from the hydrophobic interaction chromatography eluted with $0.05 \mathrm{M}$ Tris- $\mathrm{HCl}(\mathrm{pH}=7)$ containing $10 \%$ ethanol was chromatographed on an ion exchange column (Pharmacia XK16) $(2 \times 1.6 \mathrm{~cm})$. The stationary phase llsed was $5 \mathrm{ml}$ of Q-sepharose- fast flow resin (Pharmacia). Different elution conditions were assayed:

- $\quad$ gradient elution with 0 to $4 \mathrm{M} \mathrm{NaCl}$ in $0.05 \mathrm{M}$ Tris- $\mathrm{HCl}(\mathrm{pH}=7)$.

- $\quad$ isocratic elution with $0.05 \mathrm{M}$ Tris- $\mathrm{HCl}(\mathrm{pH}=7)$ containing $0.2 \mathrm{M} \mathrm{NaCl}$.

- $\quad$ isocratic elution, the phycocyanin fraction was previously dialyzed against $50 \mathrm{mM}$ acetate buffer $(\mathrm{PH}=5)$. The column was equilibrated with $50 \mathrm{mM}$ acetate buffer $(\mathrm{pH}=5)$; the sample was loaded, and the column was washed with this acetate buffer and with $0.05 \mathrm{M}$ Tris- $\mathrm{HCl}(\mathrm{pH}=7)$; fin ally, the sample was eluted with $0.05 \mathrm{M}$ Tris- $\mathrm{HCl}(\mathrm{pH}=7)$ containing $0.2 \mathrm{M} \mathrm{NaCl}$.

In all cases, the sample was eluted with $50 \mathrm{ml}$ of each mobile phase at a flow rate of $2 \mathrm{ml} \mathrm{min}$. The elution was monitored at $620 \mathrm{~nm}$ and the fractions obtained were characterized spectrophotometrically. 


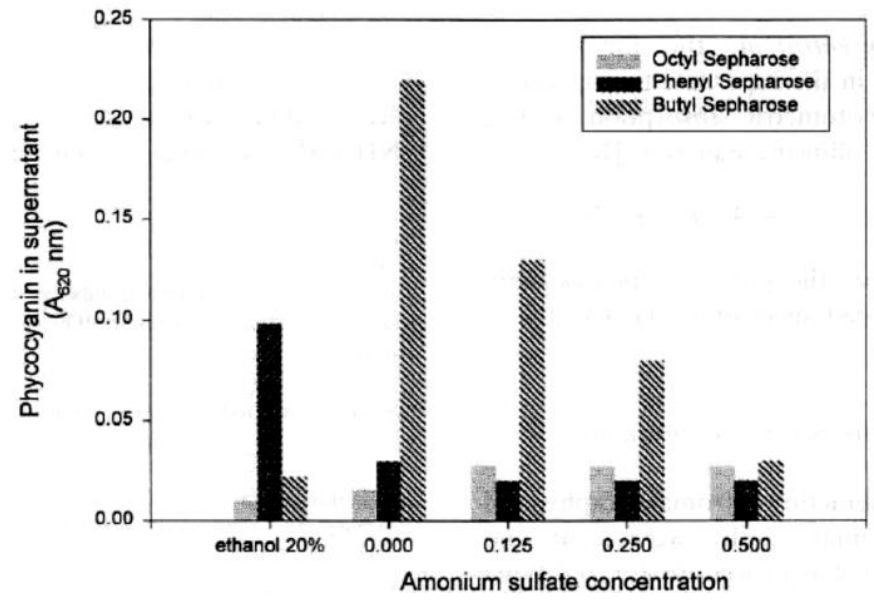

Fig. 2. Evaluation of different hydrophobic interaction resins for the purification of Synechococcus sp. IO9201 phycocyanin.

Table 3

Evaluation of elution systems and mobile phases used in hydrophobic interaction chromatography (butyl-sepharose) for the purification of Synechococcus sp. IO9201 phycocyanin

\begin{tabular}{llll}
\hline Elution system & Mobile phase & $\begin{array}{l}\text { Purity }\left(A_{620} /\right. \\
\left.A_{280}\right)\end{array}$ & Recovery (\%) \\
\hline Gradient & $0.5-0 \mathrm{M}\left(\mathrm{NH}_{4}\right)_{2} \mathrm{SO}_{4}$ in $0.05 \mathrm{M} \mathrm{Tris}-\mathrm{HCl}(\mathrm{pH}=7)$ & 3.8 & 43.1 \\
gradient & $0.5-0 \mathrm{M}\left(\mathrm{NH}_{4}\right)_{2} \mathrm{SO}_{4}$ in $0.05 \mathrm{M} \mathrm{Tris}-\mathrm{HCl}(\mathrm{pH}=7)$ containing $50 \%$ & 2.9 & 60.7 \\
& ethanol & 2.8 & 61.2 \\
Isocratic & $0.05 \mathrm{M} \mathrm{Tris}-\mathrm{HCl}(\mathrm{pH}=7)$ containing $25 \%$ ethanol & 3.1 & 72.2 \\
Isocratic & $0.05 \mathrm{M}$ Tris- $\mathrm{HCl}(\mathrm{pH}=7)$ containing $10 \%$ ethanol & 3.1 & 64.5 \\
Isocratic & $0.05 \mathrm{M}$ Tris- $\mathrm{HCl}(\mathrm{pH}=7)$ & \\
\hline
\end{tabular}

\subsubsection{Phycocyanin purification procedure from Synechococcus sp. IO9201}

On the basis of the results obtained in the previous sections, phycocyanin from Synechococcus $\quad$ sp. IO9201 was purified using the most suitable method. A clarified crude extract obtained by the freezing at $-21^{\circ} \mathrm{C}$ - thawing at $4{ }^{\circ} \mathrm{C}$ method and with the alkaline buffer was diluted with $0.05 \mathrm{M}$ Tris- $\mathrm{HCl}(\mathrm{pH}=7)$ containing $0.5 \mathrm{M}\left(\mathrm{NH}_{4}\right)_{2} \mathrm{SO}_{4}$ to obtain an absorbance of 1.1 at $620 \mathrm{~nm}$. A total of $100 \mathrm{ml}$ of this extract was applied to an hydrophobic interaction column containing $20 \mathrm{ml}$ of butylsepharose. The column was previously equilibrated with $0.05 \mathrm{M}$ Tris- $\mathrm{HCl}(\mathrm{PH}=7)$ and $0.5 \mathrm{M}\left(\mathrm{NH}_{4}\right)_{2} \mathrm{SO}_{4}$. After the sample was loaded the column was eluted with $0.05 \mathrm{M}$ Tris- $\mathrm{HCl}(\mathrm{pH}=7)$ containing $10 \%$ ethanol. The chromatography was recorded at 280 and $620 \mathrm{~nm}$.

The fractions corresponding to phycocyanin were pooled and dialyzed against 50 $\mathrm{mM}$ acetate buffer $\mathrm{pH}=5$. 
The dialyzed sample was applied to anion exchange column containing Qsepharose. The column was equilibrated with $50 \mathrm{mM}$ acetate buffer $\mathrm{pH}=5$ and after the sample was loaded, the column was washed with the same buffer. Later, the column was washed with $0.05 \mathrm{M}$ Tris- $\mathrm{HCl}(\mathrm{pH}=7)$ and the sample was eluted with $0.05 \mathrm{M}$ Tris- HCI ( $\mathrm{pH} 0$ 7) containing $0.2 \mathrm{M} \mathrm{NaCl}$. The chromatographywas recorded at 280 and $620 \mathrm{~nm}$.

\subsection{Molecular characterization of the phycocyanin extracted from Synechococcus sp. IO9201}

\subsection{Molecular weight estimation}

Molecular weight estimation of the native Synechococcus sp. IO9201 phycocyanin was performed under nondenaturing conditions by gel filtration chromatography. The sample was injected on a Superdex $200(28$ x $1 \mathrm{~cm}$, Pharmacia $)$ HPLC column and eluted with $0.05 \mathrm{M}$ Tris-HCI $(\mathrm{pH}=7)$ buffer containing $0.1 \mathrm{M} \mathrm{NaCl}$ at a Row rate of $0.5 \mathrm{ml} \mathrm{min}$. The column was previously equilibrated with the same buffer. The chromatography was monitored at $280 \mathrm{~nm}$.

The column was calibrated with the following standard proteins: apoferritin (443000), $\beta$-amylase (200 000), lactate dehydrogenase (140 000), Bovine serum albumin (66 000), carbonic anhydrase (29 000) and cytochrome c (12 400).

\subsubsection{Isoelectric focusing}

The isoelectric point of the purified phycocyanin was estimated by isoelectric focusing. An horizontal electrophoresis chamber (Multiphor II, Pharmacia Biotech) with a polyacrylamide gel (Ampholine PAG plate, Pharmacia Biotech) was used. The carrier electrolytes were of wide $\mathrm{pH}$ range (3.5-9.5). The separation was run at a constant power of $30 \mathrm{~W}$ and a controlled temperature of $10^{\circ} \mathrm{C}$. The anode solution was 1 $\mathrm{M} \mathrm{H}_{3} \mathrm{PO}_{4}$ and the cathode solution was $1 \mathrm{M} \mathrm{NaOH}$.

The isoelectric point of phycocyanin was determined using protein markers of known isoelectric points: trypsinogen $(p I=9.30)$, lentil lectil basic $(8.65)$, lentil lectil middle (8.45), lentil lectil acidic (8.15), myoglobin basic (7.35), myoglobin acidic (6.S5), carbonic anhydrase (human) (6.55), carbonic anhydrase (cow) (5.S5), $\beta$ - 
lactoglobulin A (5.20), trypsin inhibitor (4.55), amyloglucosidase (3.50). Proteins were visualized with a staining solution PhastGel Blue R (PharmaciaBiotech).

\subsubsection{Determination of the molecular weight bySDS-PAGE}

SDS-PAGE was performed with an Excel SDS Homogeneous 12.5 gel (Pharmacia Biotech) as described in [19]. Proteins were detected by the same procedure used for isoelectric focusing. Thestandard proteins were: phosphorilase b (94 000), bovine serum albumin (67 000), ovalbumin (43 000), carbonic anhydrase (30 000), soya-bean trypsin inhibitor (20 100) and $\alpha$-lactalbumin (1 4000).

\section{RESULTS}

\subsection{Evaluation of different methods for the extraction of phycocyanin from Synechococcus sp.IO9201}

The different methods used for the extraction of phycocyanin showed the presence of this molecule in the Synechococcus sp. IO9201. The absorption spectra of the extracts from this cyanobacterium showed a single peak at $620 \mathrm{~nm}$, corresponding to C-phycocyanin (Fig. 1) [20].

Three extraction methods were assayed and their efficiency was determined by means of the phycocyanin concentration and purity (expressed as $A_{620} / A_{280}$ ratio). The highest phycocyanin concentration $\left(13.42 \mu \mathrm{g} \mathrm{ml}^{-1}\right)$ and the higher purity (0.27) were obtained with the freezing at $-21{ }^{\circ} \mathrm{C}$-thawing at $4^{\circ} \mathrm{C}$ method (Table 1). Once the freezing at $-21^{\circ} \mathrm{C}$ - thawing at $4^{\circ} \mathrm{C}$ method was selected for the extraction of phycocyanin from Synechococcus sp. IO9201, different extraction solutions were assayed to obtain higher concentrations and purity than with distilled water. The results are showed in Table 2 . The highest concentration $\left(27.11 \mu \mathrm{g} \mathrm{ml}^{-1}\right)$ and purity $(0.43)$ were obtained with the alkaline solution containing $0.5 \mathrm{~g} \mathrm{l}^{-1} \mathrm{NaHCO}_{3}$ and $0.5 \mathrm{~g} \mathrm{l}^{-1} \mathrm{CaCO}_{3}$ $(\mathrm{pH}=10.5)$. The remaining extraction solutions yielded worse results than those obtained with distilled water. 


\subsubsection{Evaluation of the purification method}

Hydrophobic interaction chromatography: hydrophobic interaction chromatography was used for the purification of phycocyanin from Synechococcus sp. IO9201, but previously different resins and different eluents were evaluated. The results are showed in Fig. 2. The data obtained indicate that the phenyl- and octyl-sepharose are not suitable for the purification of this phycocyanin because the protein is adsorbed too strongly to the resin and the recovery is very low (19 and $8.9 \%$, respectively). The highest recovery was achieved with the butyl-sepharose resin.

Table 4

Evaluation of elution systems and mobile phases used in ion exchange chromatography (Q-sepharose) for the purification of Synechococcus sp. IO9201 phycocyanin

\begin{tabular}{llll}
\hline Elution system & Mobile phase & $\begin{array}{l}\text { Purity }\left(A_{620} /\right. \\
\left.A_{280}\right)\end{array}$ & Recovery (\%) \\
\hline Gradient & $0-4 \mathrm{M} \mathrm{NaCl}$ in $0.05 \mathrm{M} \mathrm{Tris}-\mathrm{HCl}(\mathrm{pH}=7)$ & 4.1 & 34.7 \\
Isocratic & $0.05 \mathrm{M} \mathrm{Tris}-\mathrm{HCl}(\mathrm{pH}=7)$ containing $0.2 \mathrm{M} \mathrm{NaCl}$ & 4.2 & 45.8 \\
Isocratic & Loading in $50 \mathrm{mM}(\mathrm{pH}=5)$ acetate buffer and eluting with $0.05 \mathrm{M}$ & 4.5 & 46.2 \\
& Tris- $\mathrm{HCl}(\mathrm{pH}=7)$ containing $0.2 \mathrm{M} \mathrm{NaCl}$ & & \\
\hline
\end{tabular}

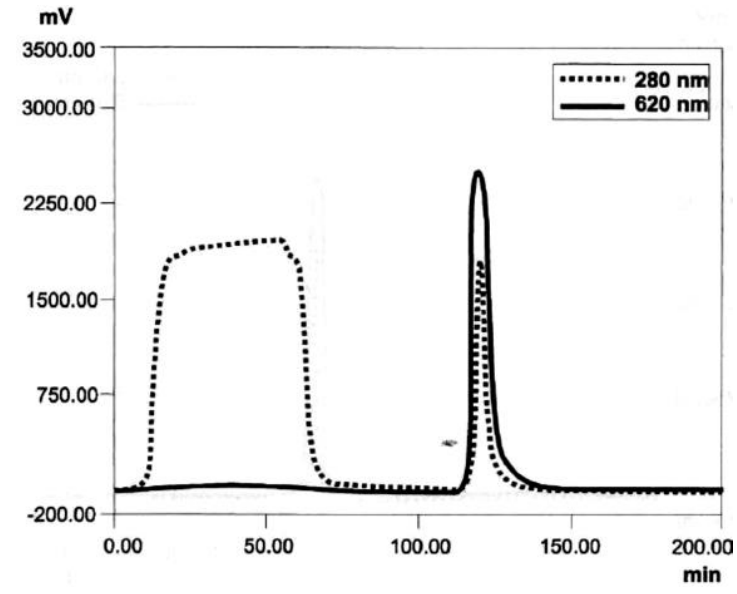

Fig. 3. Chromatogram of phycocyanin crude extract obtained by hydrophobic interaction chromatography on butyl-sepharose recording the absorbance at 280 and $620 \mathrm{~nm}$.

Once the resin was selected, the purification of phycocyanin was performed by means of hydrophobic interaction chromatography using this resin. Different elution conditions were assayed. Table 3 shows that the best purity (3.8) was obtained with the gradient system using $0.5 \mathrm{M}$ to $0 \mathrm{M}\left(\mathrm{NH}_{4}\right)_{2} \mathrm{SO}_{4}$ in $0.05 \mathrm{M}$ Tris- $\mathrm{HCl}(\mathrm{pH}=7)$ although recovery was low (43.1\%) In comparison with isocratic system using $0.05 \mathrm{M}$ Tris - $\mathrm{HCl}$ $(\mathrm{pH}=7)$ containing $10 \%$ ethanol $(72.20 \%)$. Since the purity values obtained with the different elution systems were very similar, the isocratic system with $0.05 \mathrm{M}$ Tris $-\mathrm{HCl}$ 
$(\mathrm{pH}=7)$ containing $10 \%$ ethanol was selected because with this system the recovery was the highest.

Ion exchange chromatography: the fraction containing the phycocyanin was applied to a Q-sepharose column and different elution systems were assayed. The results are showed in Table 4 . The best purity (4.5) and recovery (46.2\%) were obtained with an isocratic system in which the extract was loaded on the column in $50 \mathrm{mM}$ acetate buffer $(\mathrm{pH}=5)$ and eluted with $0.05 \mathrm{M}$ Tris- $\mathrm{HCl}(\mathrm{pH}=7)$ containing $0.2 \mathrm{M}$ $\mathrm{NaCl}$.

\subsubsection{Purification of phycocyanin from Synechococcus sp. IO9201}

With the obtained results, Synechococcus sp. 109201 phycocyanin was purified by hydrophobic interaction chromatography and ion exchange chromatography using the suitable methods. Fig. 3 shows the chromatogram obtained from hydrophobic interaction chromatography on butyl-sepharose recording the absorbance at 280 and 620 $\mathrm{nm}$. The sharp peak detected at 620 and $280 \mathrm{~nm}$ is the phycocyanin and the wide peak detected only at $280 \mathrm{~nm}$ corresponds to contaminating molecules present in the extract. After hydrophobic interaction chromatography, the recovery was $83.4 \%$ with a purification factor of 3.1 .

Fig. 4 shows the chromatogram obtained from ion exchange chromatography on Q-sepharose recording the absorbance at 280 and $620 \mathrm{~nm}$. Only one peak was obtained, both at 280 and $620 \mathrm{~nm}$, corresponding to phycocyanin. The purity factor was 4.85 and the recovery was $76.56 \%$ in relation to the crude extract. The results from the purification procedure are shown in Table 5. The spectrophotometric characterization of the different phycocyanin fractions eluted in each purification step confirms the results obtained (Fig. 5).

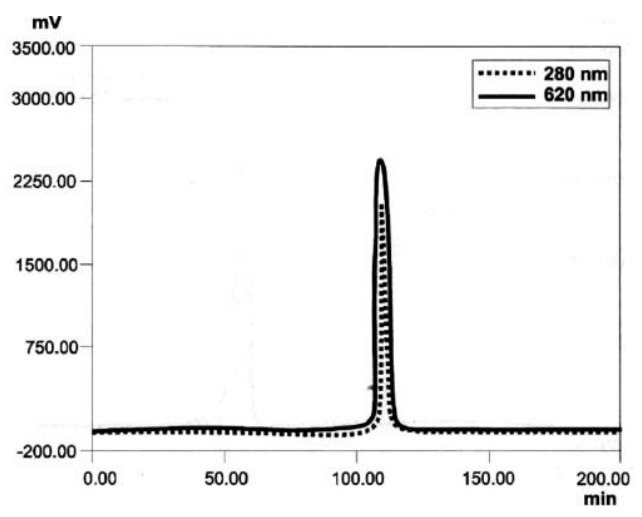

Fig. 4. Q-sepharose chromatography of the hydrophobic interaction fraction containing the phycocyanin. The absorbance was recorded at 280 and $62011 \mathrm{~m}$. 


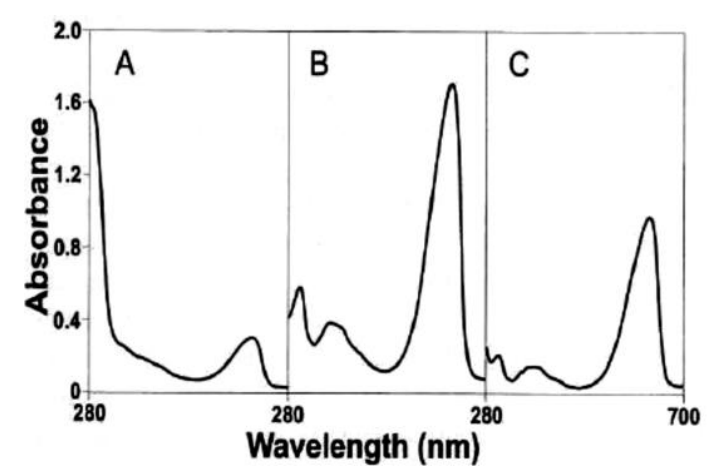

Fig. 5. Absorption spectra of Synechococcus sp. IO9201 phycocyanin. (A) Crude extract. (8) After hydrophobic interaction chromatography. (C) After ionexchange chromatography.

\subsubsection{Determination of the molecular weight}

The molecular weight of the native purified phycocyanin was determined by gel filtration on a Superdex 200 column. The molecular weight obtained was $102960 \pm 670$ daltons (Fig. 6).

\section{1.4. Determination of the isoelectric point}

The isoelectric point of the native phycocyanin purified was determined by isoelectric focusing. The phycocyanin fraction was detected in a single band with an isoelectric point of 4.6 (Fig. 7).

\subsubsection{Molecular weight by SDS-PAGE}

Two bands (A and B) were observed on the gels and their molecular weights were calculated to be $21360 \pm 980$ and $18980 \pm 870$ Da, respectively (Fig. 8)

Table 5

Summary of the purification of Synechococcus sp. IO9201 phycocyanin

\begin{tabular}{lll}
\hline $\begin{array}{l}\text { Purification } \\
\text { step }\end{array}$ & $\begin{array}{l}\text { Purification factor } \\
\left(A_{620} / A_{280}\right)\end{array}$ & Recovery $(\%)$ \\
\hline Crude extract & 0.43 & 100 \\
Butyl-sepharose & 3.2 & 83.4 \\
Q-sepharose & 4.85 & 76.56 \\
\hline
\end{tabular}




\section{DISCUSSION}

One of the most important requirements in obtaining phycobiliproteins from cyanobacteria is achieving an optimum extraction and purification procedure. In the present paper an evaluation of the isolation and purification methods for an optimum analysis of phycocyanin extracted from Synechococcus sp. IO9201 is reported. Some molecular properties of an homogeneous preparation of the Synechococcus sp. 109201 phycocyanin were also presented.

Some Synechococcus spp. are able to synthesize both phycocyanin and phycoerythrin in response to ecological conditions. Synechococcus clone IO9201 was isolated from superficial seawater and only phycocyanin was detected under the illumination conditions used in the culture; the absorption maximum at $620 \mathrm{~nm}$ (Fig. I) indicates the presence of this pigment, which coincided with those of C-phycocyanin. Therefore, the purified phycobiliprotein from this organism was identified as Cphycocyanin. The dominance of this species in the ocean offers the possibility of using it to obtain phycocyanin, since phycoerythrin is not present and this molecule does not interfere in the purification procedure.

Techniques used to extract and purify proteins are also applied to the phycobiliproteins, but a purification procedure that works well for a phycobiliprotein from one organism may not be the method of choice for the corresponding phycobiliprotein from another organism. For this reason, the best procedure to obtain an efficient purification of phycocyanin from Synechococcus sp. IO9201 was investigated.

For the efficient purification of phycocyanin from Synechococcus sp. IO9201 different steps were used. In each step, different systems were assayed. First, different extraction methods were assayed. The extraction procedure and extraction buffers used can greatly affect the pigment recovery. Highest concentrations and purity were obtained when Synechococcus cells were broken by freezing at $-21^{\circ} \mathrm{C}$-thawing at $4{ }^{\circ} \mathrm{C}$ (Table 1). This method is usually used to extract pigments from cryptomonads [21,22] and besides of this, it is an economical method. Other method used to extract biliproteins from cryptomonads was by freezing in liquid nitrogen - thawing at $4^{\circ} \mathrm{C}$ [23], this method was used with Synechococcus sp. 10920 I cells, but it gave worse results than freezing at $-21{ }^{\circ} \mathrm{C}$-thawing at $4{ }^{\circ} \mathrm{C}$ (Table 1). Cyanobacteria are usually 
ruptured with a French press or by ultrasonication [24,25], but ultrasonication did not give good results with Synechococcus sp. IO9201 cells (Table I).
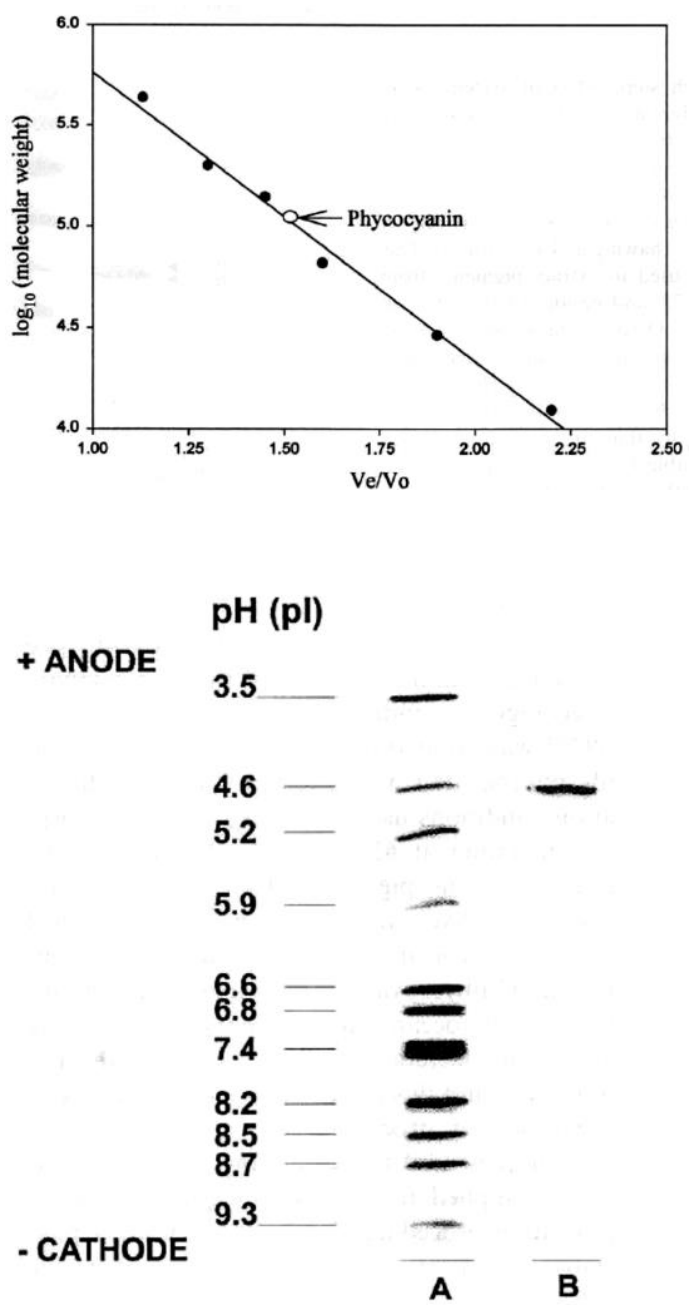

Fig. 6. Determination of the molecular weight of native phycocyanin from Synechococcus Sp. IO9201.

Fig. 7. Separation of phycocyanin from Synechococcus sp. IO9201 by isoelectric focusing. (A) Protein markers of known isoelectric point: trypsinogen $(p I=9.30)$, lentil lectil basic (8.65), lentil lectil middle (8.45), lentil lectil acidic (8.15), myoglobin basic (7.35), myoglobin acidic (6.85), carbonic anhydrase (human) (6.55), carbonic anhydrase (cow) (5.85), $\beta$-lactoglobulin A (5.20), trypsin inhibitor (4.55), amyloglucosidase (3.50). Phycocyanin purified from Synechococcus sp. IO9201.

The extraction buffer composed of $0.5 \mathrm{~g} \mathrm{l}^{-1} \mathrm{NaHCO}_{3}$ and $\left.0.5 \mathrm{~g} \mathrm{l}^{-1} \mathrm{CaCO}\right)(\mathrm{PH} \sim$ 10. 5) was the most suitable for extracting phycocyanin from Syncehocoecus sp. IO9201 (Table 2). Phosphate buffer and distilled water were used to extract phycocyanin from Anabaena sp. and cryptomonads [5,23] but these buffers gave worse results with Synechococcus sp. IO9201. Calcium chloride was also used to extract phycocyanin from Spirulina maxima with good results [II], but the extraction of phycocyanin from Synechococcus sp. IO9201 using this solution was poor. 
Once the suitable extraction method was determined, hydrophobic interaction chromatography and ion-exchange chromatography were used for the purification steps.

The pigments extracted are usually salted out with ammonium sulphate and after dialyzed overnight. To avoid the dialyzed step, hydrophobic interaction chromatography was used. Using this chromatographic technique instead of dialysis allows to do other purification step, which improves the purification. Different resins were evaluated for hydrophobic interaction chromatography since choosing the right hydrophobic ligand is of considerable importance in protein recovery. Synechococcus sp. IO9201 phycocyanin was absorbed too strongly to octyl-sepharose and therefore, very strong eluting conditions would be required (Fig, 2). In contrast, butyl-sepharose was more suitable for phycocyanin recovery.

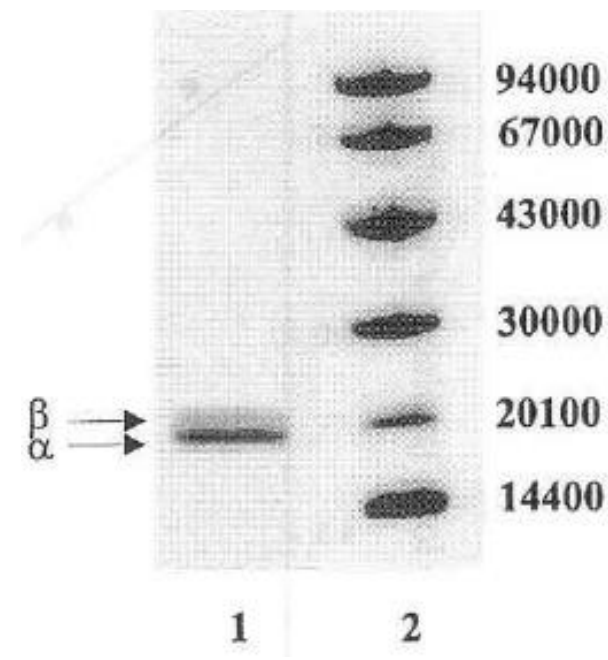

Fig. 8. SDS-PAGE of purified pbycocyanin from Synechococcus sp. IO9201. Lane I, phycocyanin from Synechococcus sp. IO9201; lane 2, marker proteins: phosphorilase b (94 000), bovine serum albumin (67 000), ovalbumin (43 000), carbonic anhydrase (30000), soya-bean trypsin inhibitor (20100) and $\alpha$-lactalbumin (14 000).

Since a variety of conditions can be used for elution from hydrophobic resins, it was necessary to select the suitable elution method for the optimum Synechococcus sp. IO9201 phycocyanin separation. In this case, after studying different elution conditions an isocratic system using $0.05 \mathrm{M}$ Tris- $\mathrm{HCl}(\mathrm{pH}=7)$ containing $10 \%$ ethanol was shown to be the best for eluting this protein and for obtaining an optimum Synechococcus sp. IO9201 phycocyanin separation (Table 3).

The next purification step was ion exchange chromatography. This procedure is the most commonly used chromatographic method for protein purification, including phycobiliproteins $[5,10,25,26]$. In the case of Synechococcus sp. IO9201 phycocyanin 
ion exchange chromatography using Q-sepharose and an isocratic system with a complex mobile phase (Table 4) yielded the best results.

C-phycocyanin is considered pure (especially for applications as a fluorescent label) when the absorption ratio of visible maximum to $280 \mathrm{~nm}$ is greater than 4.0. With the purification protocol used in this work, the purification factor obtained was 4.85 (Table 5); in other works the purity factor obtained for phycobiliproteins was 3.91, 6.13 or $2.10[10,11,27]$. This purification procedure resulted in a homogeneous preparation as seen by the single protein band obtained by nondenaturing electrophoresis. This same result was obtained in the isoelectric focusing gel (Fig. 8).

The purified phycocyanin from Synechococcus sp. IO9201 had a molecular weight of $102960 \pm 670 \mathrm{Da}$ on gel permeation and a $p I=4.6$. The phycocyanin was separated by SDS-PAGE to determine its subunit composition. The electrophoresis revealed two bands with molecular weights of $18980 \pm 870$ and $21360 \pm 980$. In accordance with the $\alpha \beta$ structure, the first band corresponds to $a$ subunit and the second one corresponds to $\beta$ subunit. The 102960 molecular weight of Synechococcus sp. IO9201 phycocyanin when divided by the monomers molecular weight suggests that it is a grouping of trimers $(\alpha \beta)_{3}(18980+21360) * 3=121020$.

In conclusion, the present work describes a complete method for the purification of C-phycocyanin from the marine cyanobacterium Synechococcus sp. IO9201. Cells were broken by freezing at $-21{ }^{\circ} \mathrm{C}$ - thawing at $4{ }^{\circ} \mathrm{C}$ and the phycocyanin was extracted by using an alkaline buffer. Hydrophobic interaction chromatography and ion exchange chromatography were used to purify the phycocyanin. With this procedure, phycocyanin was purified with an $A_{620} / A_{280}$ of 4.85 .

Obtained data for phycocyanin Synechococcus sp. IO9201 are in accordance with a trimeric structure of this molecule.

\section{REFERENCES}

1. E. Gantt, Phycobilisomes, Ann. Rev. Plant Physiol., 32 (1981), pp. 327-347

2. C. Gómez-Lojero, B. Pérez-Gómez, G. Prado-Flores, D.W. Krogmann, A. Cárabez-Trejo, A. Peña-Diaz, The phycobilisomes of the cyanobacterium Arthrospira (Spirulina) maxima, Int. J. Biochem. Cell Biol., 29 (1997), pp. 1191-1205 
3. W.A. Sidler, Phycobilisome and phycobiliprotein structures, D.A. Bryant (Ed.), The Molecular Biology of Cyanobacteria, vol. 1, Kluwer Academic, Dordrecht, The Netherlands (1994), pp. $140-216$

4. G. Cohen-Bazire, D. Bryant, Phycobilisomes: composition and structure, N. Carr, B. Whitton (Eds.), The Biology of the Cyanobacteria, Blackwell, New York (1982), pp. 143191

5. A. Ducret, W. Sidler, E. Wehrli, G. Frank, H. Zuber, Isolation, characterization and electron microscopy analysis of a hemidiscoidal phycobilisome type from the cyanobacterium Anabaena sp. PCC 7120, Eur. J. Biochem., 236 (1996), pp. 1010-1024

6. N.R. Hayashi, K. Terazono, N. Hasegawa, T. Kodama, Y. Igarashi, Identification and characterization of phycobiliprotein from a thermophilic cyanobacterium, Chroococcidiopsis sp. strain TS-821, J. Ferment. Bioeng., 84 (1997), pp. 475-477

7. J. Marquardt, H. Senger, H. Miyashita, S. Miyachi, E. Mörschel, Isolation and characterization of biliprotein aggregates from Acaryochloris marina, a Prochloron-like prokariote containing mainly chlorophyll d, FEBS Lett., 410 (1997), pp. 428-432

8. A.N. Glazer, Photosynthetic accesory proteins with bilin prosthetic groups, E.E. Conn, P.K. Stumpf (Eds.), The Biochemistry of Plants, vol. 8, Academic Press, New York (1981), pp. $51-96$

9. K.S. Rowan, Photosynthetic Pigments of Algae, Cambridge University Press, Cambridge (1989), p. 334

10. M. Duerring, G.B. Schmidt, R. Huber, Isolation, cryastallization, crystal structure analysis and refinement of constitutive C-phycocyanin from the chromatically adapting cyanobacterium Fremyella diplosiphon at 1.66 Å resolution, J. Mol. Biol., 217 (1991), pp. $577-592$

11. A. Herrera, S. Boussiba, V. Napoleone, A. Hohlberg, Recovery of c-phycocyanin from the cyanobacterium Spirulina maxima, J. Appl. Phycol., 1 (1989), pp. 325-331

12. A.N. Glazer, Phycobiliproteins - a family of valuable, widely used fluorophores, J. Appl. Phycol., 6 (1994), pp. 105-112

13. Z. Cohen, Products of microalgae, A. Richmond (Ed.), Handbook of Microalgae Mass Culture, CRC Press, Boca Raton, FL (1986), pp. 421-454

14. N. Iijima, I. Fujii, H. Shimamatsu, S. Katoh (1982) Patent No.: P1150-726-A82679.

15. J.G. Stockner, N.J. Antia, Algal picoplankton from marine and freshwater ecosystems: A multidisciplinary perspective, Can. J. Fish. Aquat. Sci., 43 (1986), pp. 2472-2503

16. I.B. Waterbury, S.W. Watson, R.R.L. Guillard, L.E. Brand, Widespread occurrence of a unicellular, marine, planctonic cyanobacterium, Nature, 277 (1979), pp. 293-294

17. J. Fábregas, J. Abalde, C. Herrero, B. Cabezas, M. Veiga, Growth of the marine microalga Tetraselmis suecica in batch cultures with different salinities and nutrient concentrations, Aquaculture, 42 (1984), pp. 207-215 
18. A. Bennett, L. Bogorad, Complimentary chromatic adaptation in a filamentous blue-green alga, J. Cell Biol., 58 (1973), pp. 419-435

19. U.K. Laemmli, Reagent and gel preparation for SDS-PAGE slab gel, Nature, 227 (1970), p. 680

20. G. Yamanaka, A.N. Glazer, Dynamic aspects of phycobilisome structure, Arch. Microbiol., 124 (1980), pp. 39-47

21. E. Mörschel, W. Wehrmeyer, Cryptomonad biliprotein: phycocyanin-645 from a Chroomonas species, Arch. Microbiol., 105 (1975), pp. 153-158

22. A.N. Glazer, G. Cohen-Bazire, A comparision of cryptophytan phycocyanins, Arch. Microbiol., 104 (1975), pp. 29-32

23. D.R.A. Hill, K.S. Rowan, The biliproteins of the Cryptophyceae, Phycologia, 28 (1989), pp. 455-463

24. D.A. Bryant, Phycoerythrin and phycocyanin: properties and occurrence in cyanobacteria, J. Gen. Microbiol., 128 (1982), pp. 835-844

25. M.P. Padgett, D.W. Krogmann, Large scale preparation of pure phycobiliprotcins, Photosynth. Res., 11 (1987), pp. 225-235

26. A.N. Glazer, The phycobilisomes, L. Packer, A.N. Glazer (Eds.), Methods of Enzymology, vol. 167, Academic Press, California (1988), pp. 304-312

27. Q. Kaixian, M. Franklin, M.A. Borowitzka, The study for isolation and purification of Rphycoerythrin from a red algae, Appl. Biochem. Biotech., 43 (1993), pp. 133-139 